\title{
Scientific support of the rice growing industry of the agroindustrial complex of the Russian Federation in solving the problems of food security
}

\author{
Vugar Bagirov ${ }^{1}$, Sergey Treshkin ${ }^{1}$, Andrey Korobka $^{2}$, Fedor Dereka ${ }^{3}$, Sergey Garkusha ${ }^{4}$, \\ Victor Kovalev ${ }^{4}$, Lyubov Esaulova ${ }^{4, *}$, and Sergey Kizinek ${ }^{5}$ \\ ${ }^{1}$ Ministry of Science and Higher Education of the Russian Federation, 125009, Tverskaya str.11, \\ Moscow, Russia \\ ${ }^{2}$ Administration of Krasnodar region, 350044, Krasnaya str.35, Krasnodar, Russia \\ ${ }^{3}$ Ministry of agriculture and processing industry of the Krasnodar region, 350044, Rashpilevskaya \\ str.36, Krasnodar, Russia \\ ${ }^{4}$ Federal State Budgetary Scientific Institution «Federal Scientific Rice Centre», 350921, Belozerny, \\ 3, Krasnodar, Russia \\ ${ }_{5}^{5}$ FSBI "Rice Stud Farm Krasnoarmeyskiy" named after A.I. Maystrenko, branch of FSBSI "Federal \\ Scientific Rice Centre", 353814, Krasnaya str.33, Oktyabrsky, Krasnoarmeiskiy district, Krasnodar \\ region, Russia
}

\begin{abstract}
According to FAOSTAT, in 2018-2019 rice was planted in 118 countries on an area of 167 million hectares, the annual grain production in the world is about 782 million tons. Rice is the most popular cereal in the diet of the Russian consumer. Rice growing is a small but rather important branch of the agro-industrial complex of the Russian Federation. The main rice producers in the world are China (over 214 million tons), India (over 172 million tons), Indonesia (83 million tons), Bangladesh (56 million tons), Vietnam (44 million tons), Thailand (32 million tons) and Myanmar (25 million tons). In the Russian Federation, rice is grown in three federal districts, in nine subjects: in the Southern Federal District - the Republic of Adygea, Kalmykia, Krasnodar, Astrakhan and Rostov Regions; North Caucasian Federal District - Republics of Dagestan and Chechen; Far Eastern Federal District - Primorsky Territory and the Jewish Autonomous Region. Scientific support of the rice-growing industry in the Russian Federation is carried out by the Federal Scientific Rice Centre.
\end{abstract}

\section{Introduction}

With an annual population growth of more than 90 million people in the world, the population will reach 9 billion by 2050 . Moreover, $90 \%$ of population growth occurs in

* Corresponding author: 1.esaulova@mail.ru 
developing countries. In this regard, the food shortage is increasing; accordingly, food production is to be increased by at least $50 \%$, bringing its annual growth to $8.5-10.0$ million tons.

Humanity annually produces more than 6 billion tons of food, almost half of which is cereals. About $70 \%$ of the grain is obtained from three crops: corn - 1020 million tons; wheat - 750 million tons and rice - 745 million tons. It is grain processing products that are indispensable sources of proteins, carbohydrates, fats and other biologically valuable substances for the body for humans.

Population growth and climate change are the most significant challenges to food security now and in the future. Population levels rise rapidly, fueling global demand and putting pressure on land due to urbanization [1].

According to FAOSTAT, in 2018-2019 rice was planted in 118 countries on an area of 167 million hectares, the annual grain production in the world is about 782 million tons. In terms of sown area, rice ranks second in the world after wheat, and in terms of yield and gross harvest, it is second in the world after corn.

More than $50 \%$ of the labor force of the agricultural sector of the planet is employed in rice growing. The demand for rice is growing annually, and according to the FAO forecast by 2030 it will amount to 790.0 million tons, exceeding the demand for wheat by $2-3 \%$.

The largest rice producers in the world are China and India - respectively, about $35 \%$ and $21 \%$ of the world volume. Large volumes of it are grown in Indonesia, Bangladesh, Vietnam, Thailand, Myanmar, Brazil, Japan, the Philippines and other countries.

Purpose of the research. Generalization of the world experience in rice production and analysis of the scientific support of the rice growing industry of the Russian Federation in solving food security problems.

\section{Materials and methods}

Descriptive, comparative and statistical research methods were used in the work. As a result of the retrospective analysis, the materials on rice production in the world and in the Russian Federation were systematized.

\section{Results and discussion}

Rice is one of the most important food crops in the world - it feeds more than 3 billion people. and provides more than $30 \%$ of the food calories consumed by humanity. According to the data (Alexandratos and Bruinsma, 2012), global rice demand is expected to grow by $28 \%$ over the next three decades [2].

Rice production has long played a vital role in ensuring national food security and political stability around the world. The largest rice producer in the world is China (214 million tons). In addition, China also consumes and imports more rice than any other country (FAOSTAT, 2017).

China has made extraordinary accomplishments in boosting its rice production. Rice yield has experienced at least two quantum jumps the first was brought by dwarf breeding the so-called «Green Evolution» in the 1960s and the second came from the introduction of hybrid rice in the 1970s. The Green Revolution has increased yields by developing highyielding varieties by introducing semi-dwarf genes into rice and wheat [3].

China is the only country in which japonica and indica are of equal importance. Twothirds of the rice grown in China is indica, which is cultivated mostly in low-altitude and low-latitude regions, and one-third is japonica, farmed prevalently in high-altitude and high-latitude regions [4]. 
Table 1. Dynamics of rice production and sowing areas in the world (FAOSTAT, 2018)

\begin{tabular}{|c|c|c|c|c|c|c|}
\hline \multirow[t]{2}{*}{ Country } & \multicolumn{3}{|c|}{2000} & \multicolumn{3}{|c|}{2018} \\
\hline & $\begin{array}{l}\text { Production } \\
\text { volume, tons }\end{array}$ & $\begin{array}{c}\text { Sown } \\
\text { area, ha }\end{array}$ & Yield, t/ha & $\begin{array}{l}\text { Production } \\
\text { volume, tons }\end{array}$ & $\begin{array}{c}\text { Sown } \\
\text { area, ha }\end{array}$ & Yield, t/ha \\
\hline Russia & 584312 & 167600 & 3.5 & 1038222 & 180177 & 5.8 \\
\hline China & 189814060 & $\begin{array}{c}30301 \\
490\end{array}$ & 6.3 & 214078796 & $\begin{array}{c}30460 \\
956\end{array}$ & 7.0 \\
\hline India & 127464896 & $\begin{array}{c}44712 \\
000\end{array}$ & 2.8 & 172580000 & $\begin{array}{c}44500 \\
000\end{array}$ & 3.4 \\
\hline Indonesia & 51898000 & $\begin{array}{c}11793 \\
000\end{array}$ & 4.4 & 83037000 & $\begin{array}{c}15995 \\
000\end{array}$ & 5.2 \\
\hline Bangladesh & 37627500 & $\begin{array}{c}10801 \\
214\end{array}$ & 3.5 & 56417319 & $\begin{array}{c}11910 \\
361\end{array}$ & 4.7 \\
\hline Vietnam & 32529500 & 7666300 & 4.2 & 44046250 & 7570741 & 5.8 \\
\hline Thailand & 25843878 & 9891200 & 2.6 & 32192087 & $\begin{array}{c}10407 \\
272\end{array}$ & 3.1 \\
\hline Myanmar & 20986900 & 6302175 & 3.3 & 25418142 & 6705577 & 3.8 \\
\hline Philippines & 12389412 & 4038085 & 3.1 & 19066094 & 4800406 & 3.9 \\
\hline Japan & 11863000 & 1770000 & 7.6 & 9727500 & 1470000 & 6.6 \\
\hline Brasil & 11134588 & 3664804 & 3.0 & 11749192 & 1861313 & 6.3 \\
\hline USA & 8657810 & 1229850 & 7.0 & 10170040 & 1179670 & 8.6 \\
\hline
\end{tabular}

The rice growing industry in Russia is an important part of the grain agro-industrial complex, in the socio-economic sphere of which it occupies a leading place. Rice is the most popular cereal in the diet of the Russian consumer. In the structure of products, rice accounts for $29 \%$, the second most popular is buckwheat with a share of $28 \%$. These types of cereals are in the lead by a wide margin. The third place is taken by oat flakes, the fourth and fifth - millet and semolina.

Rice is an important source of fiber, minerals, proteins, vitamins, antioxidants, and other biomolecules that can act synergistically and have beneficial effects on health [5].

Domestic rice cultivation is the northernmost in the world, covering a significant area between latitude $45^{\circ}$ in Krasnodar Region up to $49^{\circ}$ in the Primorsky Territory. Since the rice-growing zones are located near the northern border of the distribution of this tropical crop, the main limiting factor holding back the growth of rice productivity is the relatively low provision of territories with thermal resources. However, the heat supply of the existing rice-growing zones makes it possible to cultivate early-ripening, mid-ripening and mid-lateripening rice varieties with a vegetation period of 100 to 125 days.

In the Russian Federation, rice is grown in three federal districts, in nine subjects: in the Southern Federal District - the Republic of Adygea, Kalmykia, Krasnodar, Astrakhan and Rostov Regions; North Caucasian Federal District - Republics of Dagestan and Chechen; Far Eastern Federal District - Primorsky Territory and the Jewish Autonomous Region. (Table 2). 
Table 2. Rice production in Russian Federation (2000-2019)

\begin{tabular}{|l|c|c|c|}
\hline \multirow{2}{*}{ Region } & \multicolumn{3}{|c|}{ Gross harvest, thousand tons } \\
\cline { 2 - 4 } & 2000 & 2010 & 2019 \\
\hline Russian Federation & 584.3 & 1060.7 & 1098.7 \\
\hline Krasnodar region & 462.4 & 828.3 & 805.4 \\
\hline Rostov region & 39.9 & 65.3 & 84.9 \\
\hline Primorsky territory & 10.6 & 66.6 & 23.7 \\
\hline Republic of Dagestan & 22.5 & 31.5 & 95.2 \\
\hline Republic of Adygeya & 8.1 & 17.7 & 44.1 \\
\hline Republic of Kalmykia & 6.7 & 16.1 & 14.2 \\
\hline Astrakhan region & 35.0 & 31.2 & 9.3 \\
\hline Chechen republic & 0.0 & 1.7 & 0.5 \\
\hline $\begin{array}{l}\text { Jewish Autonomous } \\
\text { Region }\end{array}$ & 0.0 & 2.3 & \\
\hline
\end{tabular}

Since 2000, in the territorial subjects of the Russian Federation, there has been an increase in sown areas, productivity and gross harvests. In 2019, the sown area in Russia was brought to 173.8 thousand hectares, the yield was $5.5 \mathrm{t} /$ ha and the gross harvest of paddy rice was 1098.7 thousand tons.

Rice is the most stable and high-yielding crop in the country. Its yield in recent years exceeds the yield of wheat by 2-3 times. Due to the peculiarities of rice cultivation, it, to a lesser extent than other grain crops, depends on the weather and climatic conditions of each particular year.

Scientific support for the rice growing industry in Russia is carried out by three research organizations: the Federal Scientific Rice Centre (Krasnodar), the Donskoy Agrarian Research Center (Zernograd) and the Primorsky Research Institute of Agriculture (Ussuriysk).

The largest rice producer in Russia, which accounts for about $80 \%$ of the country's gross rice production, is the Krasnodar region. The sown area of rice in the Kuban $(2018,2019)$ amounted to more than 125.0 thousand hectares, the gross harvest is more than 900.0 thousand tons with a yield of $6.4 \mathrm{t} / \mathrm{ha}$. The collection of grain per unit area, achieved in recent years in the Krasnodar region, is at the level of such European countries as Italy, Spain, Turkey.

In many countries of the world, in particular, in China, Bangladesh, breeding work has recently been carried out to create rice hybrids that have some form of resistance to biotic or abiotic stresses and are more responsive to fertilization and use of water resources [6].

More than 100 resistance genes or loci have been identified to date. $R$ genes are distributed on 11 chromosomes of rice genome, except chromosome 3, and more than $64 \%$ are clustered in chromosomes 6,11 and 12 , representing $18 \%, 25 \%$ and $21 \%$, respectively (Ashkani et al., 2016). The development of molecular biology has brought rice breeding to the stage of combining biotechnology with conventional technology. In the last decade, molecular breeding technology, represented by molecular marker-assisted selection, has played an important role in the improvement of rice blast resistance in elite recipients [7].

In the breeding work of Federal Scientific Rice Centre, the following main directions are highlighted: breeding of technogenically intensive varieties with a yield potential of $12 \mathrm{t}$ / ha; development of varieties for cultivation using energy-saving technologies; breeding of varieties resistant to biotic and abiotic stressors; development of special-purpose varieties (long-grain, large-grain, glutinous, high-amylose, with colored pericarp, etc.); development 
of varietal complexes in order to more fully use the bioclimatic potential of rice agricultural landscapes and the yield potential of the crop.

Varieties for cultivation using intensive and energy-saving technologies with increased resistance to blast and a yield potential of up to 11-12 tons per hectare were developed (Rapan, Flagman, Istok, Patriot, Apollon, Nautilus, Kumir, Polevik, Favorit, Diamant, Sonet). Thanks to effective breeding work, fast variety change and the introduction of adaptive varietal complexes, taking into account agrolandscape zoning, a high yield of rice has been achieved in Krasnodar region.

To improve the resilience of agri-food systems in global agriculture, climate risk management strategies are widely promoted at various levels. According to data (Challinor et al., 2014), it was found that with adaptation at the level of crops, the increase in productivity of the main global food products (corn, wheat and rice) can increase by $7-15 \%$ compared with those without adaptation. [8].

In this regard, scientists from Federal Scientific Rice Centre carried out large-scale environmental and industrial tests of new and promising rice varieties in different agricultural landscapes of Krasnodar region, which made it possible to develop varietal complexes that maximize the biological and adaptive potential of varieties depending on the agro-ecological quality of lands. Recommendations have been developed to improve the efficiency of rice growing on the basis of targeted, landscape-oriented and economically justified implementation.

The most obvious change that breeders must respond to is the emergence of new races and biotypes of pathogens and pests that overcome resistance in existing varieties [9, 10]. More consumer-centered approaches will then be required to ensure plant breeding meets changing preferences and quality requirements in domestic and international markets. [11].

Global warming and declining water resources are threatening the sustainability of rice production and global food security. Conventional continuously flooded system (CF) of rice production is a major contributor to rice production but it requires a huge amount of water input and poses a severe threat to the ecosystem due to emission of greenhouse gases (GHGs) and accumulation of heavy metals [e.g., arsenic (As) and mercury (Hg)] in the rice grains. The declining soil health, increasing micronutrient deficiencies, and declining organic matter are are also threatening the long term sustainability of the conventional rice production system [12].

The implementation of breeding programs at the Federal Scientific Rice Centre provides for the use of methods of biotechnology, physiology, genetics. With the help of marker breeding, work is being carried out to pyramid genes of race-specific blast resistance and genes of wide spectrum into the most common varieties of various morphotypes.

In the State Register of Breeding Achievements, approved for use in production in Russia for 2020, there are 69 rice varieties, of which 32 varieties were bred by the Federal Scientific Rice Centre, which accounted for $96.4 \%$ of the crops in Krasnodar region, and $79.8 \%$ in the Russian Federation. \%, and on gross harvest $-97.8 \%$ and $85.4 \%$, respectively.

Providing farms with high-quality seeds is essential in increasing the efficiency of the rice-growing industry. organization of elite and primary seed production. Every year Federal Scientific Rice Centre produces more than 4 thousand tons of elite seeds, which provides crops with seeds not lower than the first reproduction.

The health of the nation is one of the most important priorities of the Russian state, and rice is known as a highly nutritious dietary product that is included in the set of essential components of a balanced human diet. This necessitates the development of the domestic rice growing industry to a level that reduces the dependence of the country's domestic market on imported rice supplies, which remains quite high today.

The introduction of new varieties and technologies using modern methods of 
biotechnology will make it possible to obtain additional products by increasing yields through variety change. The balance of rice in Russia consists of its own production and imports. Rice imports to Russia are about 200-250 thousand tons per year (in 2017 - 227.9 thousand tons; in 2018 - 210.7 thousand tons). Milled rice is imported to the Russian Federation from Thailand, Vietnam, China, Pakistan, India.

According to the Federal Customs Service, almost all rice imported into Russia is longgrain, its share is $95.6 \%$, short-grain, crushed and medium-grain rice account for $1.1 \%$, $0.7 \%, 2.6 \%$, respectively. It should be noted that 10 years ago the share of short-grain rice in the import structure was $46.1 \%$. At present, with an increase in acreage and gross harvests in Russia, the market for round-grain rice has reached its maximum and displaced imports. At the same time, the share of long-grain rice in the import structure increased from 50\% in 2006 to $95.6 \%$ in 2018 . The structure of imports also includes varieties of the exclusive group (red-grain, black-grain, wild rice, glutinous, large-grain, etc.), as well as rice products (flakes, rice flour, etc.).

The export of rice by Russia in recent years is 180-200 thousand tons (in 2017 - 178.9 thousand tons; in 2018 - 228.9 thousand tons), including $40-50 \%$ of rice grain. The main exporting countries are Turkey, Belgium. More than $80 \%$ of medium-grain, $4.1 \%$ of longgrain, $10.6 \%$ of crushed and $1.4 \%$ of short-grain are exported. According to the degree of processing, more than $50 \%$ of the country's export is unhulled rice. New sales markets allow to increase exports.

The potential of Russia's rice growing allows for the annual production of about 1.5 million tons of rice-grain, and significantly increase the supply of rice for export.

A special problem for the domestic rice market is the quality and safety of imported rice products. White long-grain rice, round-grain low-amylose, paraboiled rice from Thailand, brown rice, aromatic Thai variety "Jasmine", "Basmati" rice, wild rice, etc. are imported into the country.

Technical measures such as sanitary and phytosanitary regulations are becoming important for a range of agricultural products, including rice, as issues such as food safety and plant and animal health become more sensitive [13].

It should be noted that rice grown in Russia is much more environmentally friendly compared to the products of most other rice-producing foreign countries. This is due to the very limited use of pesticide treatments of rice crops - 1-3 for the growing season, as well as the widespread use of new generation selective preparations, characterized by high selective action, low application rate and short decay period. The use of mineral fertilizers is also characterized by moderate doses, and often insufficient for the full realization of the productivity potential of varieties. All this indicates a low chemogenic load on rice agricultural landscapes and a high environmental friendliness of Russian rice growing.

In the perspective of the development of rice production in the Russian Federation until 2030 , it is necessary to increase the sown area for this crop to 200-230 thousand hectares. If a scientifically grounded crop rotation is observed, it is possible to increase the cultivated areas in Krasnodar region to 140 thousand hectares, and to provide another 90 thousand hectares of rice in other rice-growing regions of the Southern and Far Eastern Federal Districts.

The dynamic and effective development of the rice growing industry in Russia depends on state regulation of the market by economic methods, including active actions by the Russian government in the rice market to support domestic producers and financial support for rice growing at the federal and regional levels.

In order to expand the range of rice products offered to potential buyers and increase exports, it is advisable:

- development and promotion of large-grain and long-grain rice varieties to the market in order to create new products to improve nutritional quality; 
- the use of domestic rice flour for the production of diet food in order to replace imported raw materials in the production of baby food and reduce the price of the finished product;

- organization of production of an assortment of rice products (rice flakes, canned rice, breakfast cereals, etc.), in order to replace imported products (the quality of which does not always meet environmental safety requirements) and reduce the price of the finished product.

The solution of the problems facing the industry is impossible without improving scientific support and increasing its role in the development of domestic rice growing.

\section{Conclusions}

The world needs to be able to produce more rice with less water, energy and land as these resources are becoming scarce in the modern day [14].

However, intensive rice cropping systems in Asia create a huge demand for these resources. Among these, land degradation-whether it is by depleting soil micronutrients, increasing soil toxicity or increasing the incidence of pests and diseases (FAO, 2010a) - is a major problem in sustaining the rice production. These issues create two major problems: (1) increased use of the chemicals and therefore increased GHG emissions and (2) a levelling off of the rice yield. Climate change may further impact rice yield as today's highyielding varieties are intolerant of higher temperatures, drought and salinity, all of which are expected to occur more often in the future. In coastal rice growing areas, rising sea levels and storms are predicted to create problems which, in extreme cases, may lead to a food crisis, given that rice is a staple food in these areas [15].

The implementation of measures to strengthen the scientific support of rice growing will make it possible to preserve the largest rice production and reclamation complex in the Russian Federation and will contribute to the more efficient use of fixed assets, ensure the further development of the existing potential and the integrated use of natural resources, significantly improve the socio-economic situation, ensuring full employment and improving the life of the population in the rice-growing regions of the Russian Federation.

With efficient farming, the saturation of rice crop rotations with rice can reach $55-60 \%$, and the sown area in the Russian Federation - 200-230 thousand hectares. Modern highly productive varieties, subject to scientifically grounded cultivation technology and resource endowment, are able to realize their productive potential and guaranteed to provide an average yield in the country of 5.5-6.5 $\mathrm{t} /$ ha (which has already been achieved in certain regions in 2015-2020).

Thus, by 2030, Russia, annually producing $1.4-1.5$ million tons of rice-grain, will be able to significantly increase its supplies abroad.

\section{Discussion}

By the decree of the President of Russia V.V. Putin dated January 21, 2020 No. 20, the Food Security Doctrine was approved, which provides for the state of the country's socioeconomic development, in which the food independence of the Russian Federation is ensured, the physical and economic accessibility of food products that meet mandatory requirements is guaranteed for every citizen of the country, in volumes not less than rational norms of consumption of food products necessary for an active and healthy lifestyle.

The rice growing industry of the agro-industrial complex of Russia is a self-sufficient industry that provides $100 \%$ of its own population with milled rice. Sustainable development of rice growing in Krasnodar region ensures food independence based on the 
principles of science-based planning; realization of the export potential, taking into account the priority of the country's self-sufficiency in domestic rice products. Russia has all the prerequisites for the further development of rice growing: irrigated areas - 220-230 thousand hectares, modern high-yielding rice varieties, seeds of higher reproductions, scientifically grounded technologies of cultivation and provision of resources.

At the same time, it is necessary to carry out annual monitoring, forecasting and control in the field of ensuring food security, taking into account the changing situation in the world rice market, changes in the natural and climatic nature.

\section{References}

1. D. Satterthwaite, G. McGranahan, C. Tacoli, Urbanization and its implications for food and farming. Philosophical Transactions of the Royal Society B: Biological Sciences, 365(1554), 2809-2820 (2010)

2. N. Alexandratos, J. Bruinsma. Global agriculture by 2030/2050.: FAO: EKA, Rome (2012)

3. T. Ding, C. Zhukuan, From Basic Research to Molecular Breeding - Chinese Scientists Play A Central Role in Boosting World Rice Production. Genomics Proteomics Bioinformatics, 16, 389-392 (2018) https://doi.org/10.1016/j.gpb.2018.12.002.

4. Y. H. Wang, Q. H. Cai, H. G. Xie, F. X. Wu, L. Lian, W. He, L. P. Chen, H. A. Xie, J. F. Zhang, Determination of heterotic groups and heterosis analysis of yield performance in indica rice. Rice Sci, 24(5), 261-269 (2018) https://doi.org/10.1108/RPJ-01-2017-0015

5. B. Burlando, L. Cornara, Therapeutic properties of components and derivatives of rice (Oryza sativa L): an updated review. Trends in Food Science and Technology, 40, 8298 (2014)

6. A. M. Shew, Environmental Science \& Policy, 95, 46-57 (2019) https://doi.org/10.1016/j.envsci.2019.02.004

7. X. Ning, Strategy for Use of Rice Blast Resistance Genes in Rice Molecular Breeding. Rice Science. 27(4), 263-277 (2020) https://doi.org/10.1016/j.rsci.2020.05.003

8. B. Subir, K. M. Ashok, D.-M. Alvaro, Climate risk management strategies and food security: Evidence from Cambodian rice farmers. Food Policy, 101935, 95, (2020) ISSN 0306-9192, https://doi.org/10.1016/j.foodpol.2020.101935.

9. P. Kapoor, Past, present and future of rice blast management. Plant Sci. Today., 1(3), 165-173 (2014) Pages. https://doi.org/10.14719/pst.2014.1.3.24

10. M. C. Custodio, M. Demont, A. Laborte, J. Ynion, Improving food security in Asia through consumer-focused rice breeding (Review). Global Food Security, 19-28, 9 (2016) DOI: 10.1016/j.gfs.2016.05.005.

11. T. T. Nguyen, The effect of Sanitary and Phytosanitary measures on Vietnam's rice exports. $\quad$ Economica, 251-265, 19(2) https://doi.org/10.1016/j.econ.2017.12.001Get rights and content

12. I. Muhammad, Alternate wetting and drying: A water-saving and ecofriendly rice production system. Agricultural Water Management, 106363, 241 (2020) https://doi.org/10.1016/j.agwat.2020.106363

13. E. Peterson, J. Grant, D. Roberts, V. Karov, Evaluating the trade restrictiveness of phytosanitary measures on U.S. fresh fruit and vegetable imports. American Journal of Agricultural Economics, 842-858, 95(4) (2013) DOI: 10.1093/ajae/aat015. 
14. M. Hafeez, J. Bundschuh, S. Mushtaq, Exploring synergies and tradeoffs: energy, water, and economic implications of water reuse in rice-based irrigation systems Appl. Energy, 889-900, 114 (2014) http://dx.doi.org/10.1016/j.apenergy.2013.08.051

15. T. N. Maraseni, An international comparison of rice consumption behaviours and greenhouse gas emissions from rice production. Journal of Cleaner Production, 22882300, 172(20) (2018) https://doi.org/10.1016/j.jclepro.2017.11.182. 